Primljen / Received: 16.5.2016. Ispravljen / Corrected: 1.9.2016.

Prihvaćen / Accepted: 30.9.2016.

Dostupno online / Available online: 10.1.2017.

\title{
Structural repair of Careva Cuprija Bridge in Sarajevo
}

\section{Authors:}

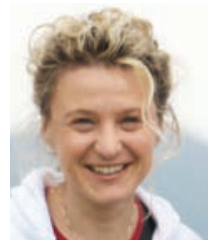

Assist.Prof. Naida Ademović, PhD. CE University of Sarajevo Faculty of Civil Engineering naidadem@yahoo.com

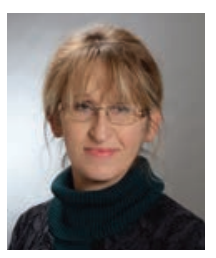

Prof. Azra Kurtović, PhD. CE University of Sarajevo Faculty of Civil Engineering azra_kurtovic@gf.unsa.ba

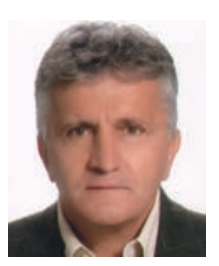

Muhamed Madžarević, MSc. CE

University of Sarajevo Faculty of Civil Engineering madzarbih@yahoo.com
Naida Ademović, Azra Kurtović, Muhamed Madžarević

Professional paper

\section{Structural repair of Careva Ćuprija Bridge in Sarajevo}

Structural condition and repair of the Careva Cuprija Bridge in Sarajevo is presented in the paper. This historic structure has been exposed to various atmospheric influences during its use, and also to significant traffic load for which it was not initially designed, which has ultimately resulted in degradation of its structure. To enable continued functioning of this bridge its structure must be repaired taking into account the fact that the bridge was proclaimed a national monument of Bosnia and Herzegovina on 11 March 2009.

\section{Key words:}

cultural-historical heritage, reinforced-concrete arch structure, repair, degradation, modelling

Stručni rad

\section{Naida Ademović, Azra Kurtović, Muhamed Madžarević}

\section{Sanacija konstrukcije mosta Careva Ćuprija u Sarajevu}

Rad prikazuje stanje konstukcije i sanaciju mosta Careva Ćuprija u Sarajevu. Ova povijesna građevina je bila izložena različitim atmosferskim utjecajima tijekom uporabe, kao i značajnim prometnim opterećenjima za koja nije projektirana, što je rezultiralo degradacijom konstrukcije. S ciljem da most zadrži svoju ulogu nužno je izvršiti sanaciju konstrukcije vodeći računa da je građevina proglašena nacionalnim spomenikom Bosne i Hercegovine 11. ožujka 2009.

Ključne riječi:

kulturno - povijesno naslijede, armiranobetonska lučna konstrukcija, sanacija, degradacija, modeliranje

Fachbericht

Naida Ademović, Azra Kurtović, Muhamed Madžarević

\section{Sanierung der Konstruktion der Careva Čuprija Brücke in Sarajevo}

Die Arbeit stellt den Zustand der Konstruktion sowie die Sanierung der Careva Čuprija Brücke in Sarajevo dar. Dieses historische Bauwerk war während seiner Nutzung verschiedenen atmosphärischen Einflüssen und bedeutendem, die projektierten Lasten überschreitendem Verkehr ausgesetzt, so dass eine Degradierung der Konstruktion ausgelöst wurde. Mit dem Ziel, die Funktion der Brücke zu erhalten, ist eine Sanierung erforderlich und zwar unter Berücksichtigung der Tatsache, dass dieses Bauwerk seit dem 11. März 2009 in Bosnien und Herzegowina als Nationaldenkmal geführt wird.

Schlüsselwörter:

kulturhistorisches Erbe, Bogenkonstruktion in Stahlbeton, Sanierung, Degradierung, Modellierung 


\section{Structure assessment methodology}

Proper and detailed investigation, and determination of correct diagnosis of the existing structure, are key factors for the design of suitable interventions on a particular structure. In this respect, various interventions may be envisaged: strengthening of individual elements, replacement of worn-down parts, addition of new elements, improvement of connections between different elements, etc. The importance of investigations for structural diagnosis (taking into account historical aspects regarding the structure, properties of materials and structure) is emphasized in the Venice Charter [1]. Characterization of an existing structure is a very complex task, which requires the use of a specific multidisciplinary evaluation methodology, as stated for instance in the ICOMOS Recommendations for the Analysis, Conservation and Structural Restoration of Architectural Heritage (ICOMOS, 2003) as shown in Figure $1[2,3]$.

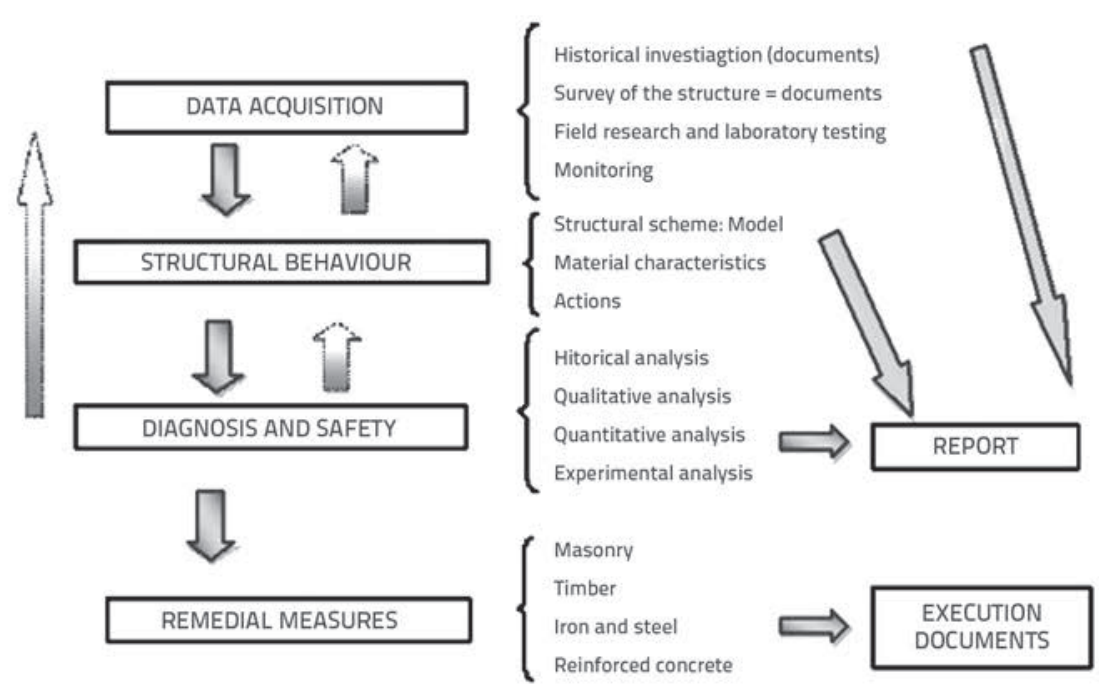

Figure 1. Methodology for structural interventions according to ICOMOS [2, 3]

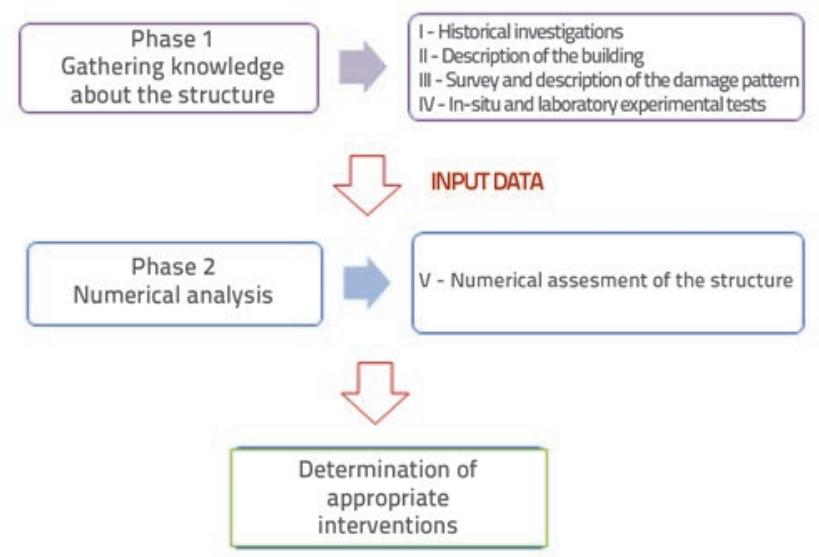

Figure 2. Analytical methodology [2, 3]

This methodology enables a clear assessment of the current physical state of the structure. The related knowledge enables development of numerical models that will subsequently be calibrated so that structural forms and mechanisms can adequately be presented. Figure 2 indicates that the methodology can be divided into two main phases:

1. Knowledge phase (historical research; description of the structure - geometry and materials; damage survey; in-situ and laboratory tests); and

2. Numerical Analysis phase (definition of the type of analysis, models and tools).

A modelling strategy for numerical assessment of structures is defined already at the knowledge phase based on the previously gathered information.

The use of this phased multidisciplinary procedure is essential for an in-depth understanding of behaviour exhibited by existing structures. This approach enables a knowledge-based structural analysis and, thus, strengthening methods can be defined with a much greater accuracy. This is also significant for avoiding unnecessary strengthening, as well as works that could make more harm than good.

\section{Historical investigations of the existing bridge structure}

As shown in Figure 2, the first step is to gather all historical information about the structure. As to the time of its construction, the Careva Cuprija Bridge (Emperor's bridge) is the oldest of all bridges in Sarajevo. The bridge was constructed by the Bosnian sanjak-bey Isa-bey Ishaković. It was built in the axis of the door of the Careva Cuprija Mosque on the left bank, and Kolobarahan on the right bank of the Miljacka River. The evidence regarding the origin of this bridge is based on the waqf deed of Isabey, and as this deed is dated between 1 February and 3 March 1462, and as Isa-bey became Bosnian governor in 1439, the bridge must have been built somewhere between 1462 and 1439. At that time, it connected the city's main north-south roadway. The bridge was originally made of wood. The Isa-bey's wooden bridge, already quite dilapidated, was rebuilt by Gazi Husrev-bey but this time the bridge was made of stone. In 1619, six Sarajevo's bridges, including this one, were destroyed by flood. The Careva Cuprija Bridge was once again reconstructed in 1629 by the Sarajevo's agha Husein Haračić.

The bridge was subsequently destroyed in the great flooding that struck the city on 15 November 1739 but was reconstructed soon thereafter by a Sarajevo merchant, Hadži Mustafa Bešlija. According to documents preserved to this day, the Careva Cuprija Bridge had four spans supported by three columns in the river and two retaining walls on the banks, as shown in Figure 3. The total span of the bridge is about 50 meters.

The Miljacka River is highly torrential in character. This torrential character of water regimen manifests itself in a wide flow and a characteristic form of flood waves. The high water to low water flow 

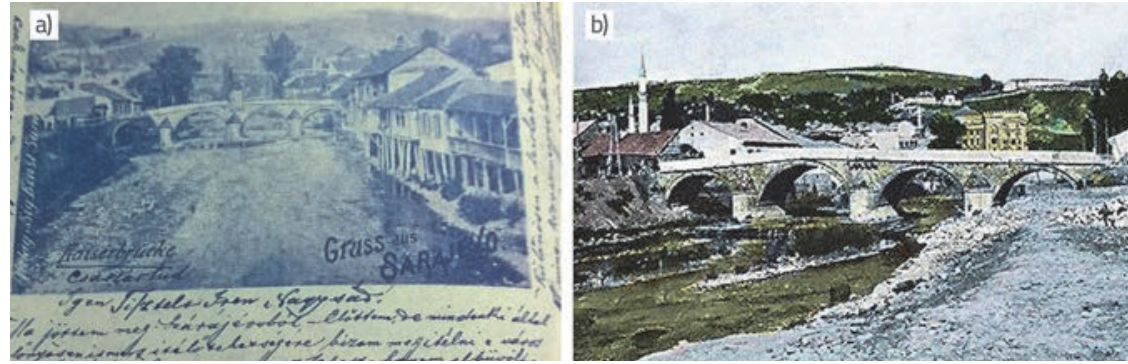

Figure 3. a) Postcard from Sarajevo showing an $18^{\text {th }}$ century Emperor's Bridge drawing; b) Stone version of the Careva Ćuprija Bridge from the $18^{\text {th }}$ century [4]
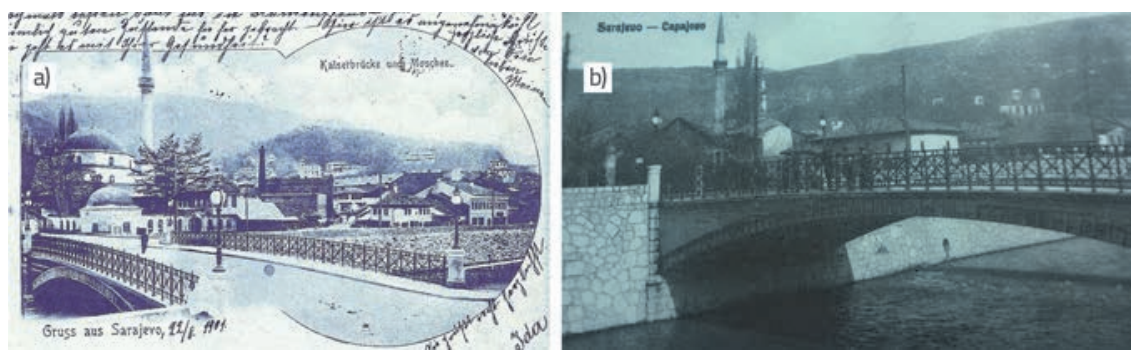

Figure 4. a) The Careva Ćuprija Bridge in 1901; b) Photograph of the Careva Ćuprija Bridge 1900.1910 [4]

ratio is in the order of $Q_{\max } / Q_{\min } \sim 10^{3}$, as opposed to large watercourses where this ratio is $Q_{\max } / Q_{\min } \sim 10$. On the other hand, the duration of high water flows is very short in case of torrential rivers, and amounts to several hours only. In the category of smaller rivers, torrential character of water regime is primarily manifested in specific genesis, rapid concentration, and short duration of high water flows.

The Miljacka River regulation plan was proposed at the Community Council meeting held on 8 March 1880. According to this plan, the bank was to be protected and strengthened on the stretch from Bentbaša to Čobanija. The old Careva Cuprija Bridge was demolished in 1897 but was immediately replaced by the new Careva Cuprija Bridge erected twenty meters upstream in the axis of the street leading to the Konak Palace. It was built as the first single-arch reinforced concrete bridge in Sarajevo and, with the span of 25.36 meters, it was the largest structure of this type in the Austro-Hungarian monarchy (Figure 4). According to some data, the bridge was built on the basis of the design made by the Czech engineer J. Pelikan / Schuster.

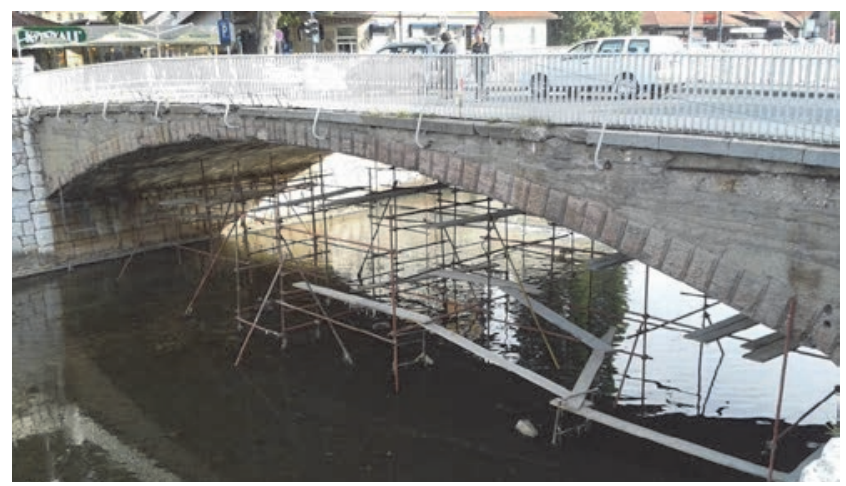

Figure 5. Careva Ćuprija Bridge with scaffolding during investigation works in 2015 [5]
During this period the bridge was used for both pedestrian and cart traffic. After the First World War, the motor vehicle traffic started to be operated across the bridge. Figure 5 shows the Careva Cuprija Bridge with scaffolding under the bridge during investigation works conducted in 2015. It can be seen that some changes were made on the bridge regarding the pedestrian railing, and that bridge lighting was removed.

\section{Description of bridge structure}

The second step involves description of bridge structure in order to determine the geometry and built-in materials, which can primarily be determined by visual inspection and in-situ measurements. Visual inspection revealed that the bridge consists of one reinforced concrete arch with a rather flat, almost radial alignment, with the height of about $5 \mathrm{~m}$ at the centre of the bridge. The arch structure is defined by the opening about 25.15 meters in length. The rise of the bridge arch is about $2.60 \mathrm{~m}$.

The bridge is founded in a traditional way on a structure composed of stone slabs on which the bank abutments of limestone were constructed (local white Hreša stone) as supports for the arch structure. The abutments were further strengthened upstream and downstream by abutment walls also made of limestone. Bank abutments are nearly perpendicular and their corners are completed with alternating quoins [6]. Along the bank there is a protection made of wooden beams and piles of variable diameter ranging from $10 \mathrm{~cm}$ to $30 \mathrm{~cm}$, spaced at 50 to $80 \mathrm{~cm}$ intervals.

\section{Visual inspection and determination of bridge damage}

After removing some concrete from the bridge arch, it was established that the bridge intrados is reinforced with rigid reinforcement consisting of $2 \mathrm{~L}$ sections measuring $60 \times 60 \times 4$ $\mathrm{mm}$ (20 sets in total), as shown in Figure 6.

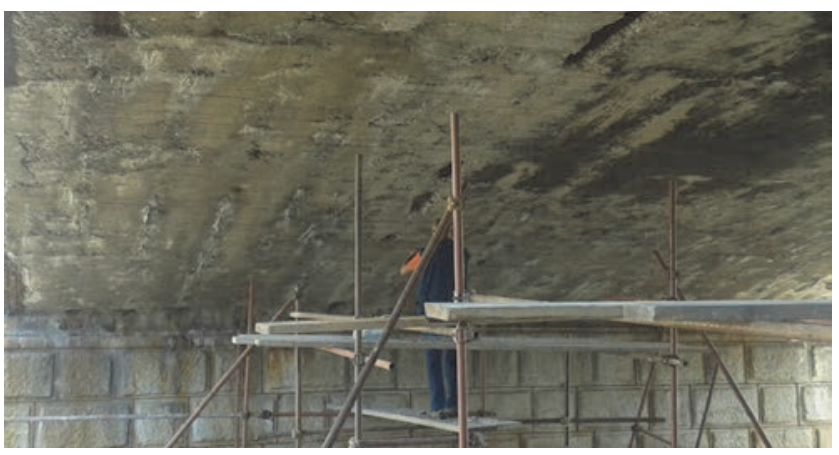

Figure 6. Location of rigid reinforcement 
Figure 7 shows the position of the reinforcement that is arranged in the transverse direction at approximately every 45 $\mathrm{cm}$ to $50 \mathrm{~cm}$ intervals, and extends along the entire length of the bridge.

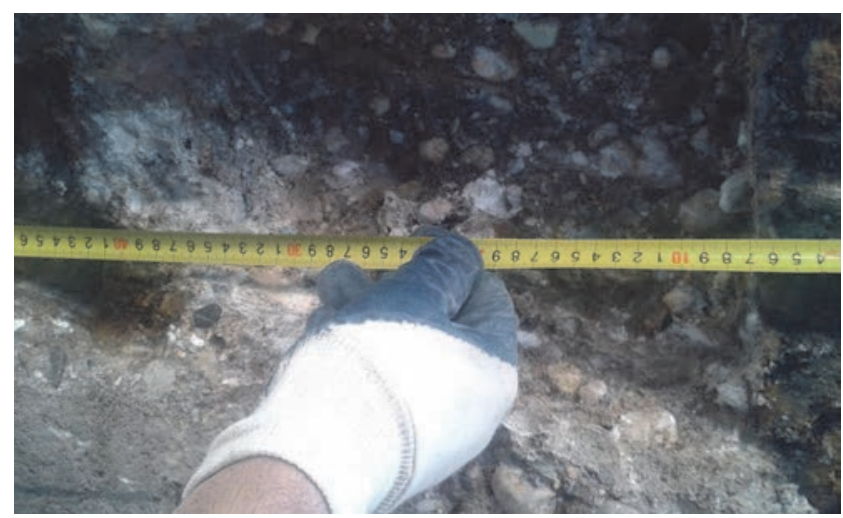

Figure 7. Rigid reinforcement spacing

The rigid reinforcement was placed along the entire span of the bridge (Figure 6) with connections at four places. Figure 8 shows rigid reinforcement connection points. The rigid reinforcement connection was realized using a steel plate about $6 \mathrm{~mm}$ thick, with a set of six rivets on each side. The steel plate measures $46 \times 13 \mathrm{~cm}$ and it is approximately $6 \mathrm{~mm}$ in thickness. Rivets are spaced at $6 \mathrm{~cm}$ intervals. Inner spacing between the rivet sets is $13.5 \mathrm{~cm}$, while the distance from the edge of the steel plate to the first (last) rivet is $4.5 \mathrm{~cm}$. The steel corrosion and scaling was registered on the steel plates used as connections for rigid reinforcement.

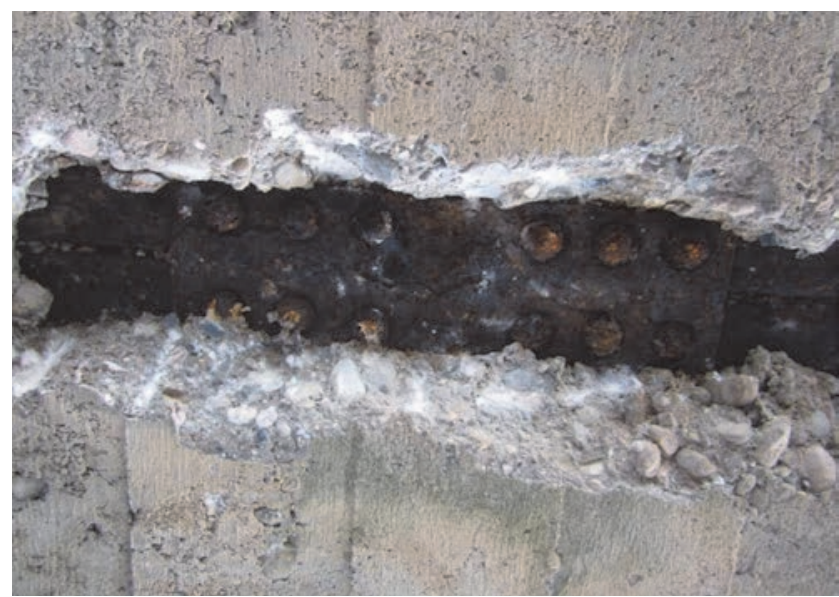

Figure 8. Rigid reinforcement connection

The bridge extrados is made of concrete with rigid reinforcement, which is placed at the ends, on both sides of the bridge (Figure 9). After removal of the top layers of the bridge structure, it will be possible to see whether this reinforcement is placed along the entire width of the bridge, as is the case with the intrados, or it is placed on the sides only. Figure 9 shows significant corrosion of the top rigid reinforcement. This reinforcement is unprotected and is directly exposed to weather, presenting significant "swelling" due to an increase in the volume of reinforcement, which indicates that the reinforcement has been greatly affected by corrosion. It is well known that parts of the structure on the east side are highly exposed to rain and wind, which has resulted in quicker degradation and impact.

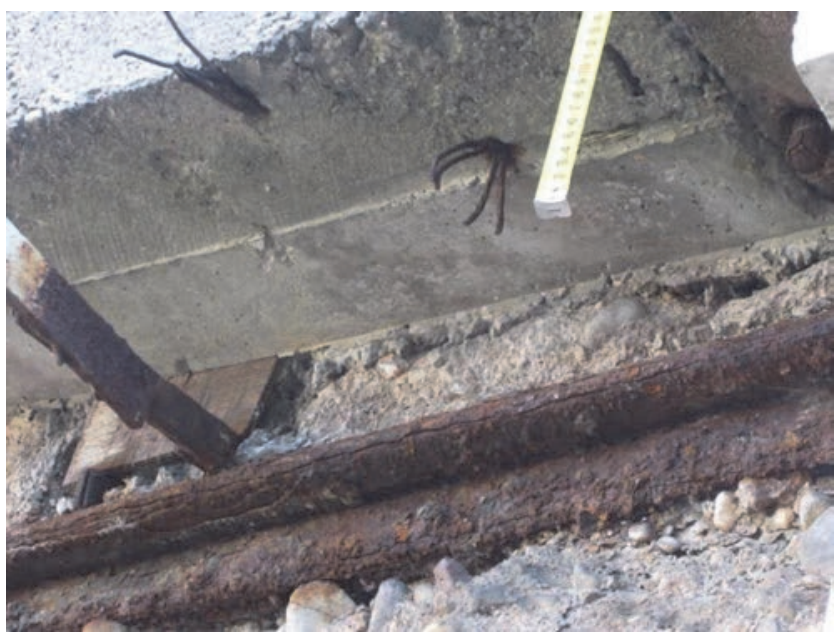

Figure 9. Corrosion of top rigid reinforcement - east façade-upstream side

The fence of the bridge is in a very poor condition (Figure 10); the entire structure of the steel fence is affected by corrosion. Also, spalling of concrete was observed on the sides of the bridge structure (east façade - upstream side of the bridge, and west façade - downstream side of the bridge) at the connection with S-shaped steel elements and their corrosion (Figure 11).

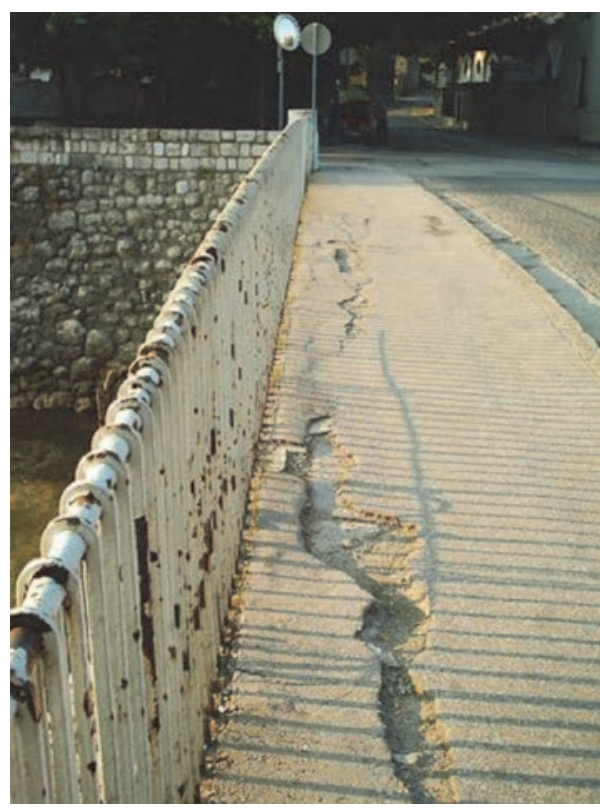

Figure 10. Corrosion of steel fence and sidewalk damage

Figure 10 shows sidewalk degradation and lack of asphalt layer. Damage to sidewalk and railing is due to the freezing and thawing 
processes. Once water is allowed to penetrate into the capillary system and it freezes, the pores and cavities are enlarged due to hydrostatic pressure, which is caused by an increase in the volume of frozen water. This pressure expands the pores and capillaries quite slowly, over a number of cycles. The damage due to freezing and thawing processes, in the form of sputtering and spalling of concrete, mainly resulting from progressive expansion of cement stone, was also registered. This freezing and thawing effect is greatly enhanced by the use of deicing salts, which are regularly used for road maintenance. This caused maximum spalling on the concrete surface. In the end, breaking and spalling of concrete led to exposure of reinforcement to corrosion due to penetration of chlorides and moisture.

A horizontal crack extending along the entire length of the sandstone lining can clearly be seen at the eastern façade (Figure 11). Due to great exposure to rain and wind action, this stone lining on the east façade suffered considerable damage, the level of which is greater compared to the damage registered at the western façade.

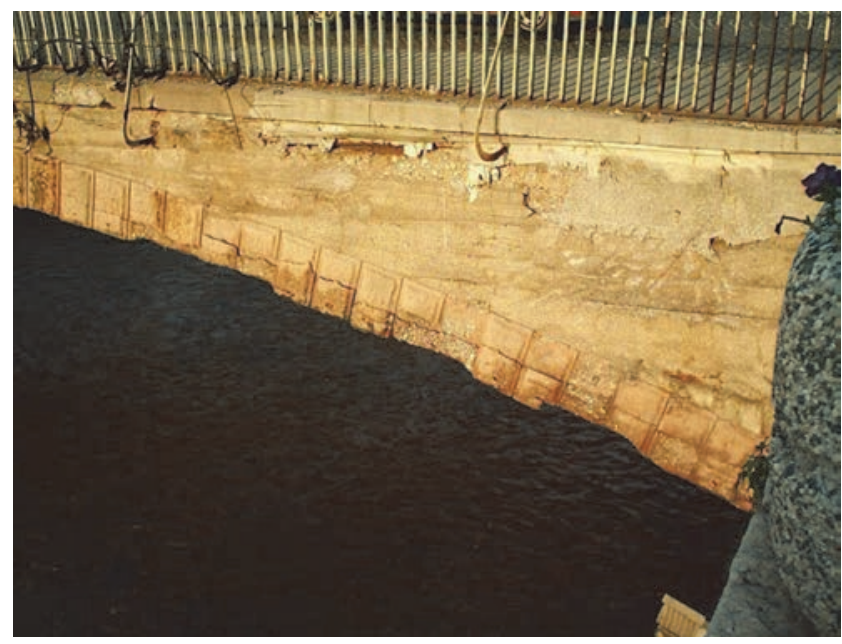

Figure 11. Detachment of decorative elements, horizontal cracks in concrete on the arch, and corrosion at the railing support east façade - upstream side

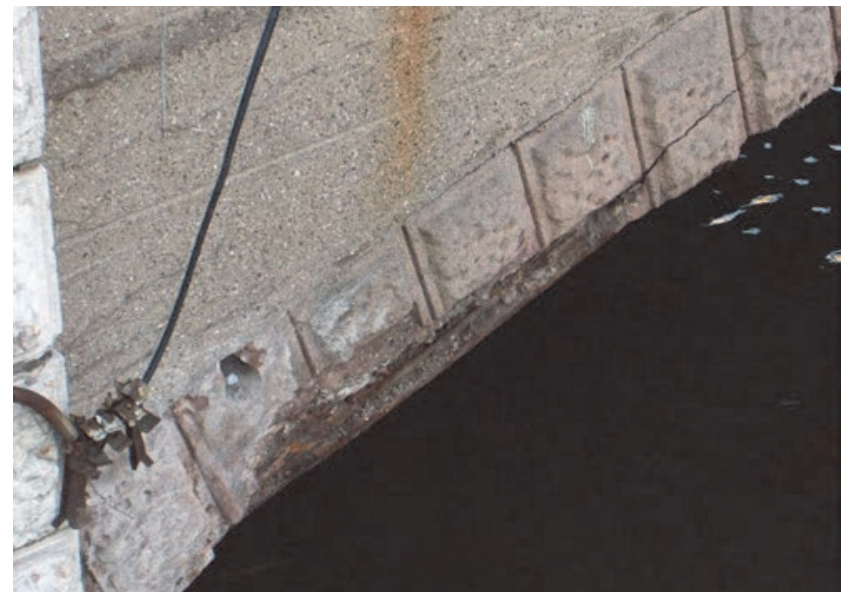

Figure 12. Horizontal cracks on the walls: east façade - upstream side
Figure 12 shows a significant horizontal crack that extends almost along the entire length of the arch on the lateral side. This crack does not affect only the decorative element but extends through the load bearing concrete structure of the arch. This is to be expected given the significant corrosion of the rigid reinforcement on the intrados. Also, vertical cracks are evident on lateral walls of the arch. Cracks generally increase the porosity of concrete and allow water, soluble salts, and chemicals to penetrate into concrete, and thus accelerate its destruction and open the way for further corrosion of the rigid reinforcement.

Significant corrosion at the bottom rigid reinforcement along the edge of the arch is shown in Figure 13, as well as the lack of concrete cover. As is known, concrete, thanks to its alkaline nature, protects steel reinforcement from corrosion. A high $\mathrm{pH}$ value enables formation of a thin protective layer of stable oxides on the steel surface, preventing further development of rust. When this protective layer of stable iron oxides is damaged by the action of acidic environment, the depassivation phenomenon inevitably occurs, i.e. the steel corrosion is initiated. The increase in reinforcement volume due to corrosion is evident, resulting in creation of internal stress, cracking and spalling of concrete. Longitudinal cracks are evident on the corroded "rigid reinforcement". Parts of rigid reinforcement that are completely "stripped" are exposed to active atmospheric actions, and so the structural capacity of these elements is compromised. This situation creates conditions for expansion of corrosion to the passivized part of rigid reinforcement.

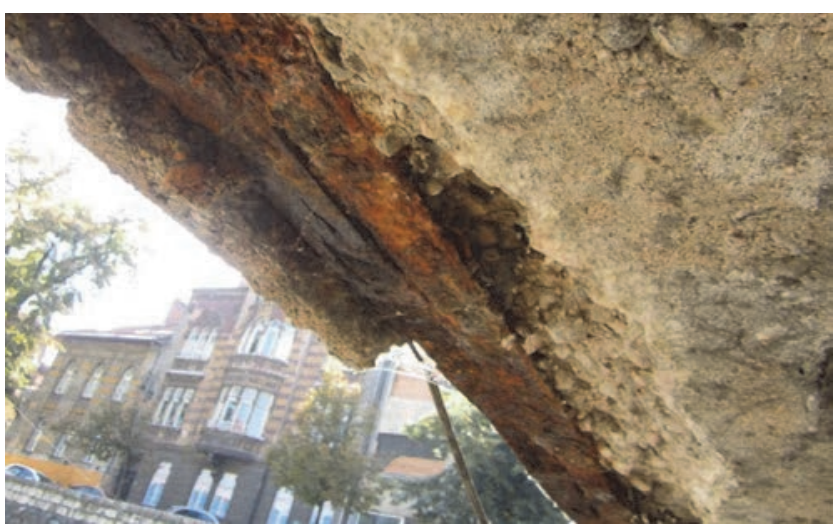

Figure 13. Corrosion of rigid reinforcement at bottom side of the arch - east façade - upstream

The entire surface of the metal is affected by general corrosion, with additional subsurface or layered corrosion. The corrosion is the most pronounced at steel parts that have been in contact with water and acids.

It should be noted that in the May 2014 flooding the level of the Miljacka River was the highest in the last ten years. It was 244 $\mathrm{cm}$ and the water reached the level of the arch spring (Figure 14), and so parts of the structure were directly exposed to the action of water. A similar situation, although at a smaller scale was registered in 31 October 2007. In the light of current information about the torrential character of the Miljacka River, the 
question regarding safety of this bridge in case of a future flood should rightfully be considered. Besides destruction of the bridge materials due to torrential character of the Miljacka River, the river carries waste materials and debris and thus causes further damage to the bridge structure and the embankment of the Miljacka River. As it is well known, the scouring process differs if it occurs in water not burdened with sediments, compared to the scouring in rivers with significant bed load.

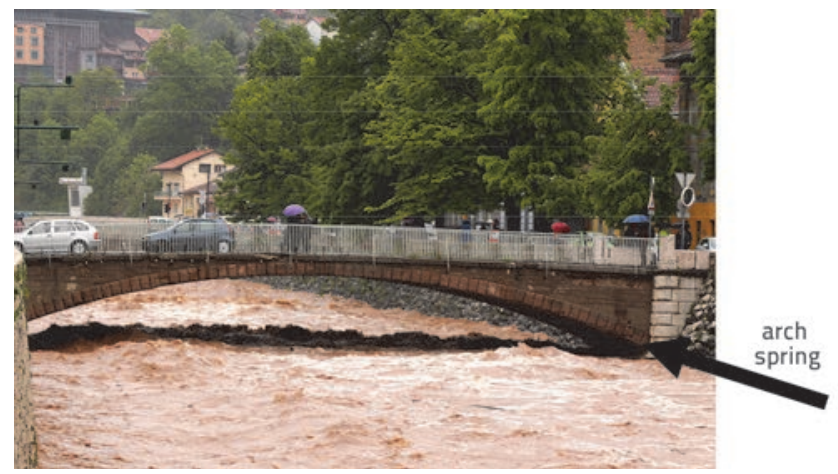

Figure 14. Flooding in May 2014

It is generally known that corrosion products (swelling) have larger volume compared to that of the destroyed materials, and that peeling with pitting expands to the depth of the material. An average penetration rate of carbon steel corrosion in the city's atmosphere ranges from 1.182 to 7.88 (mm/year).

Figures 15 and 16 show that carbonation of concrete occurs when carbon dioxide from the air penetrates into the concrete and reacts with hydroxides, such as calcium hydroxide, forming carbonates. In the reaction with calcium hydroxide, calcium carbonate is formed. This process reduces the $\mathrm{pH}$ value of the solution within pores to less than 11.8 and, at that level, the passive iron oxide film on the steel becomes unstable, leading to corrosion. Carbonation is largely dependent on relative humidity. The greatest carbonation level occurs when the relative humidity is maintained in the range between $50 \%$ and $75 \%$. Just like chloride ions, the carbonation destroys the passive film on the reinforcement, but has no effect on the corrosion rate.

Water from the carriageway penetrated through filling material to the concrete arch and caused flow-assisted corrosion (corrosion of soft water). It is known that on its way the seepage water dissolves calcium hydroxide (product of Portland cement hydration), which is deposited on the surface of the concrete where it reacts with $\mathrm{CO}_{2}$ (carbon dioxide) contained in the atmosphere, forming a relatively solid, hard, well-adherent, bright coating of calcium carbonate $\left(\mathrm{CaCO}_{3}\right)$ appearing in form of downward oriented jets. Eventually, they spread and become thicker ruining the surface, and assuming the form of stalactites or stalagmites. Their formation is evident along the entire bottom surface of the bridge (intrados) in locations of rigid reinforcement. The stalactites are approximately $20 \mathrm{~cm}$ in length and about half a centimetre in diameter.

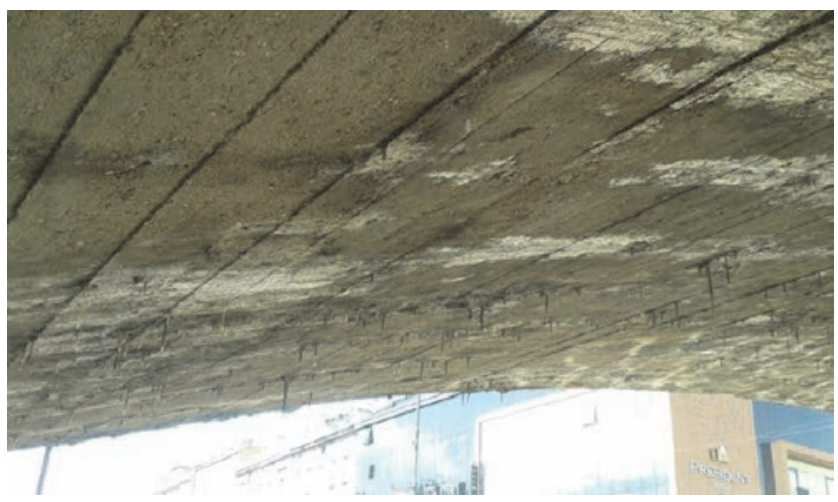

Figure 15. Carbonation of intrados and formation of stalactites

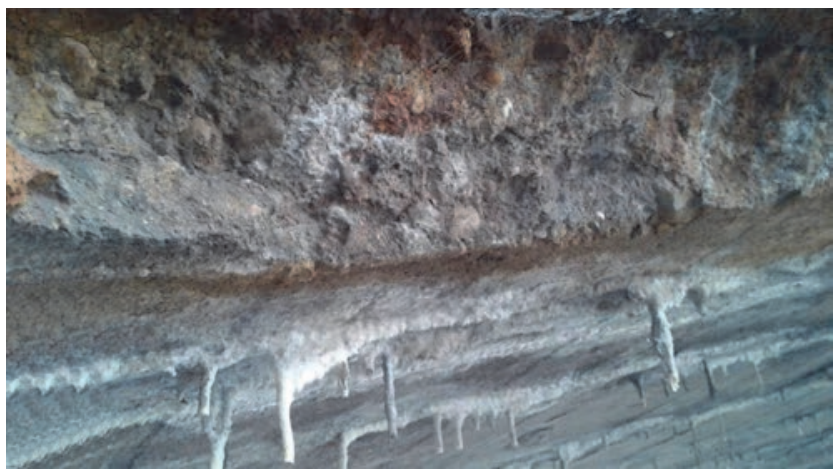

Figure 16. Carbonation of intrados and formation of stalactites

In addition to the flow-assisted corrosion, the concrete on this bridge is also exposed to general acid corrosion. General acid corrosion is formed by the action of from the environment $\mathrm{CO}_{2}$ on the cement stone, which results in a chemical reaction. Carbon dioxide and water form carbonic acid which reacts with $\mathrm{Ca}(\mathrm{OH})_{2}$ forming $\mathrm{CaCO}_{3}$; however other compounds of the cement stone decompose and water is released in the process. Therefore, the bridge is affected by soft water corrosion (flowassisted corrosion) in combination with general acid corrosion.

Figures 17 and 18 show formation of deposits on the abutment. This deposit is up to $20 \mathrm{~cm}$ in thickness and it peels off and separates from stone blocks that are placed around the abutments of the bridge structure. Figure 19 also clearly shows significant corrosion of rigid reinforcement near the left abutment on the downstream side. This corrosion penetrates through significant deposits that have formed as a result of corrosion release. The carbonation results in a decrease in concrete alkalinity.

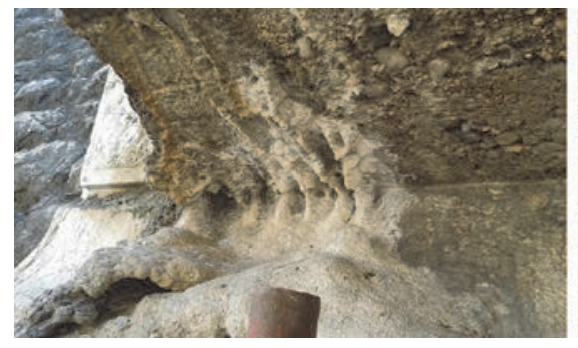

Figure 17. Deposits at left abutment - east side

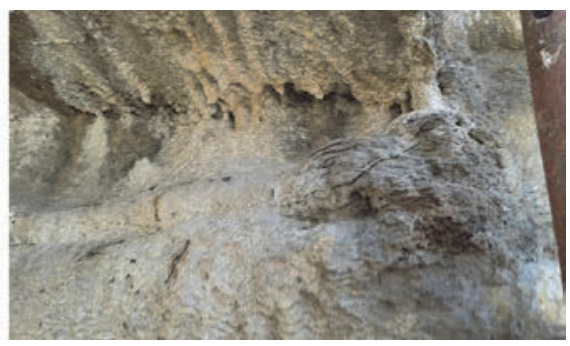



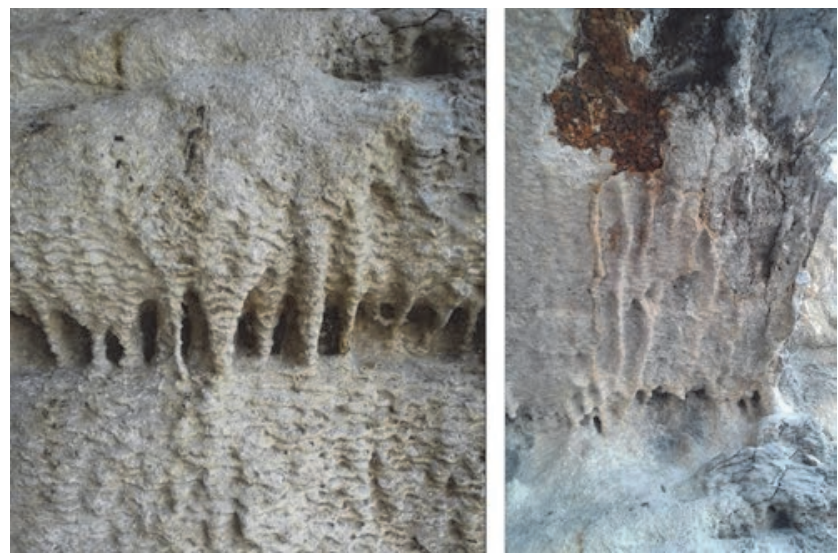

Figure 18. Deposits at left abutment - east side

Figure 19 shows rigid reinforcement at the intrados. The rigid reinforcement consists of $2 \mathrm{~L}$ sections measuring $60 \times 60 \times 4 \mathrm{~mm}$, which are separated by a layer of concrete $1 \mathrm{~cm}$ in thickness. The overall width of the rigid reinforcement and concrete amounts to $13 \mathrm{~cm}$. A significant corrosion was observed after removal of concrete cover ( $5 \mathrm{~cm}$ ) (Figure 20). The steel peeling can clearly be distinguished. The degree of steel corrosion varies depending on the position of the rigid reinforcement and the existence or absence of concrete cover. Overall, it can be stated that the rigid reinforcement is highly corroded.

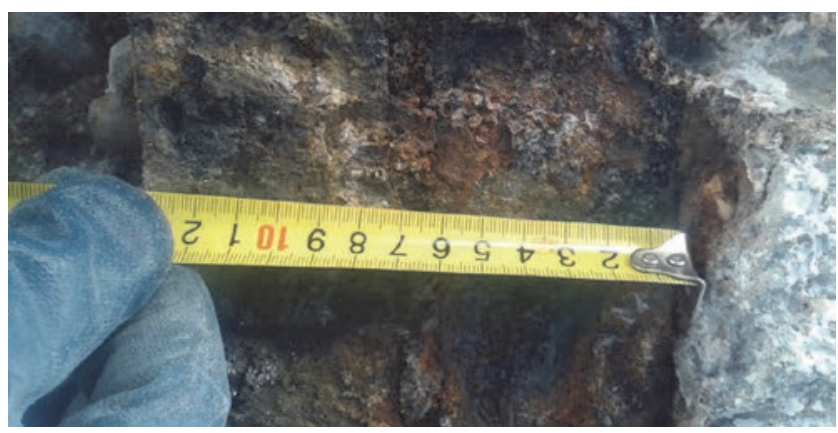

Figure 19. Rigid reinforcement

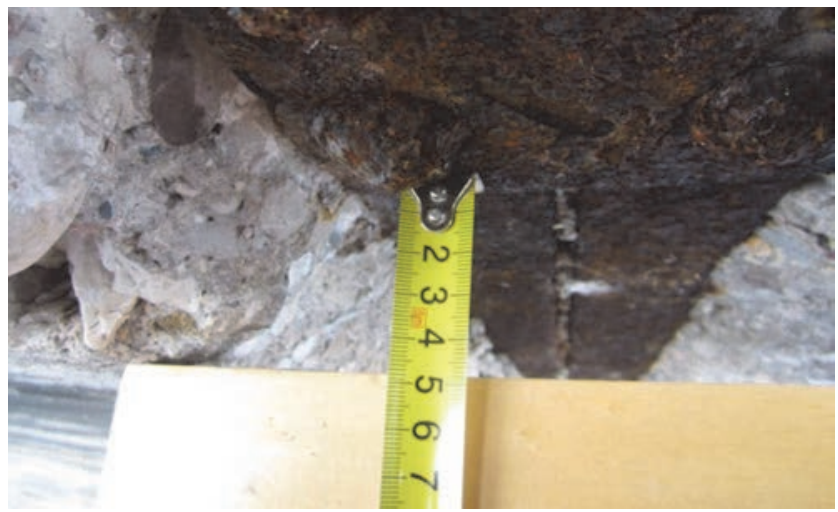

Figure 20. Thickness of concrete cover

After removal of stone blocks (Figure 21) at the location of left abutment, it was observed that the stone blocks serve exclusively as lining.
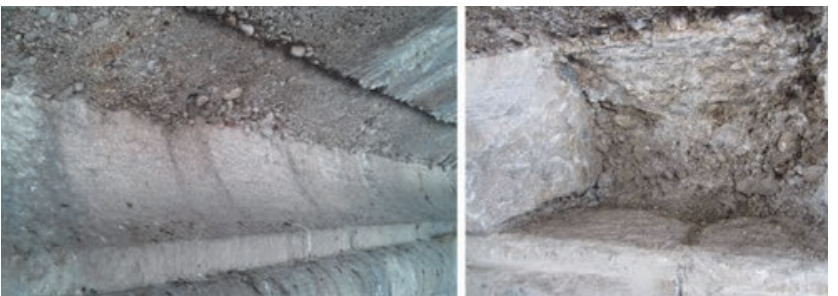

Figure 21. Abutment stone blocks at the left bank of the river and situation after their removal

A part of the Miljacka river bank is protected by wooden beams and piles placed between two beams (Figure 22). Wooden piles are of variable diameter ranging from approximately $10 \mathrm{~cm}$ (smaller) to $30 \mathrm{~cm}$ (bigger ones). They are spaced at approximately 50 to $80 \mathrm{~cm}$ from each other. As investigations were conducted in dry period (August 2015), it was noted that wooden piles are not fully covered with water, but are free of water some $5-8 \mathrm{~cm}$.
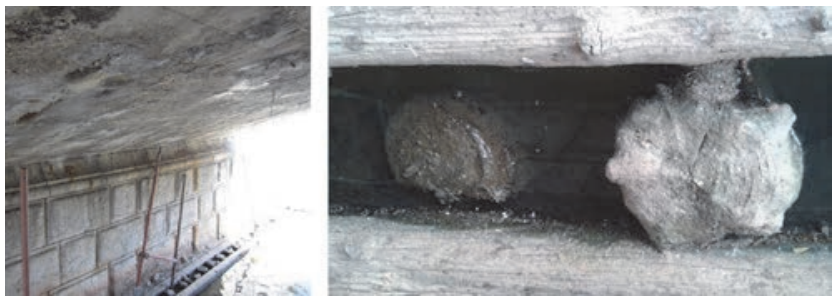

Figure 22. Wooden piles and beams along the Miljacka river bank

\section{Onsite investigations and laboratory tests}

The bridge structure was tested in 2007 by the Institute of Materials and Structures of the Civil Engineering Faculty in Sarajevo [7]. At that time, 12 cores were taken from the side walls and the arch in order to determine the current concrete class. Due to the fact that this is a structure belonging to cultural and historical heritage, the testing was conducted based on regulations that have been in force for many years (JUS, Regulations PBAB / 87, etc.). Additional five cores were taken from the top side of the bridge structure in order to determine the state of the bridge structure in 2015, and whether there has been a further degradation in the quality of concrete (Figure 23) [8]. The number of samples for destructive testing was determined taking care to afflict as little damage as possible to the existing structure. Control testing was performed by sclerometer using a nondestructive method.

Due to unavailability of information regarding the bridge rehabilitation, which evidently took place after partial investigation works in 2007, and as it was impossible to find the original design of the bridge (the bridge documentation was not found in any of the archives of the Bosnia \& Herzegovina), the decision was made to make investigations of the bridge utilizing destructive methods taking care to gather the strictest minimum of samples that would enable finding proper information about the state of the bridge. 


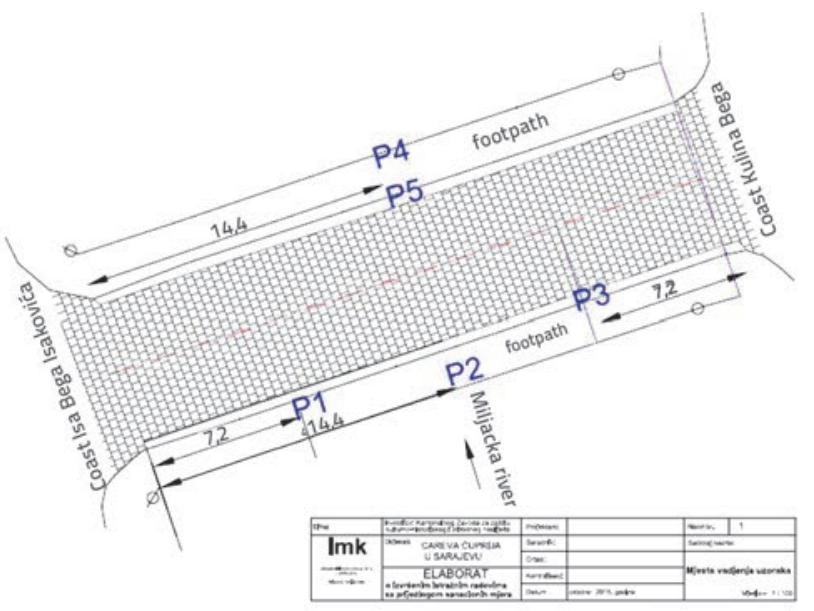

Figure 23. Location of samples [8]

After sampling, it was established that the thickness of the arch varies not only along the arch, but that the thickness in the crown is also not constant (Table 1).

Table 1. Cross-section of cylindrical samples taken from the crown

\begin{tabular}{|l|c|c|c|}
\hline \multirow{2}{*}{ Layers [cm] } & \multicolumn{3}{|c|}{ Sample designation } \\
\cline { 2 - 4 } & P2 & P4 & P5 \\
\hline Asphalt & 6 & 4 & 6 \\
\hline "New asphalt" & - & 20 & - \\
\hline Filling and bulk material & 22 & 16 & 22 \\
\hline Crown & 53 & 44 & 34 \\
\hline Total sample height & 81 & 84 & 62 \\
\hline
\end{tabular}

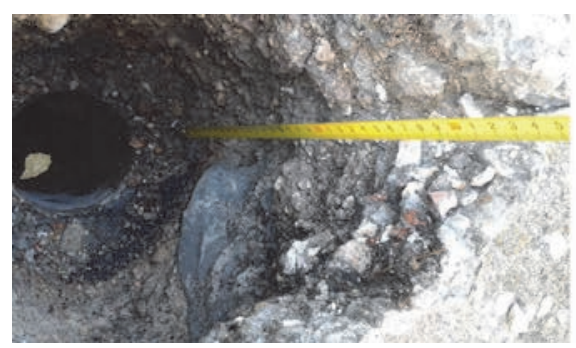

Figure 24. Waterproofing tar layer

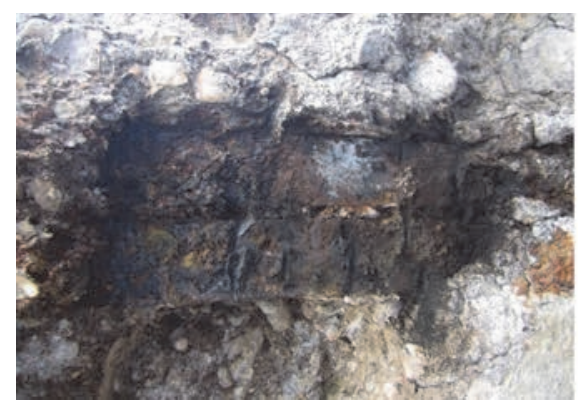

Figure 25. Steel hardness testing
A waterproofing tar layer ranging from 5 to $8 \mathrm{~mm}$ in thickness was found on top of the extrados (Figure 24).

\subsection{Determination of material characteristics}

\subsubsection{Rigid reinforcement}

Steel hardness was tested on the site using the POLDI method. The testing of steel hardness of the rigid reinforcement located on the intrados of the bridge is shown in Figure 25. Based on testing conducted on rigid reinforcement $2 \mathrm{~L} 60 \times 60 \times 4 \mathrm{~mm}$, the steel can be classified as steel class Č 0545 according to JUS standards (according to EN 10027-1 E295, and DIN St 502 ), with the tensile strength of $470 \mathrm{~N} / \mathrm{mm}^{2}$, and the yielding strength of $285 \mathrm{~N} / \mathrm{mm}^{2}$.

\subsubsection{Built in concrete}

Figure 26 shows one of the samples extracted at the crown of the bridge and a sample taken in 2007 , so that the quality of concrete can be compared.

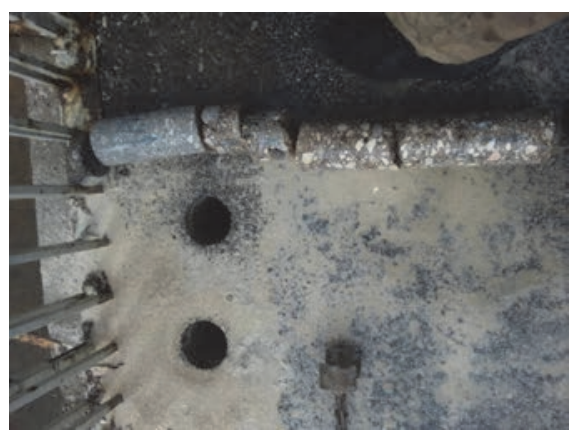

Figure 26. Concrete samples
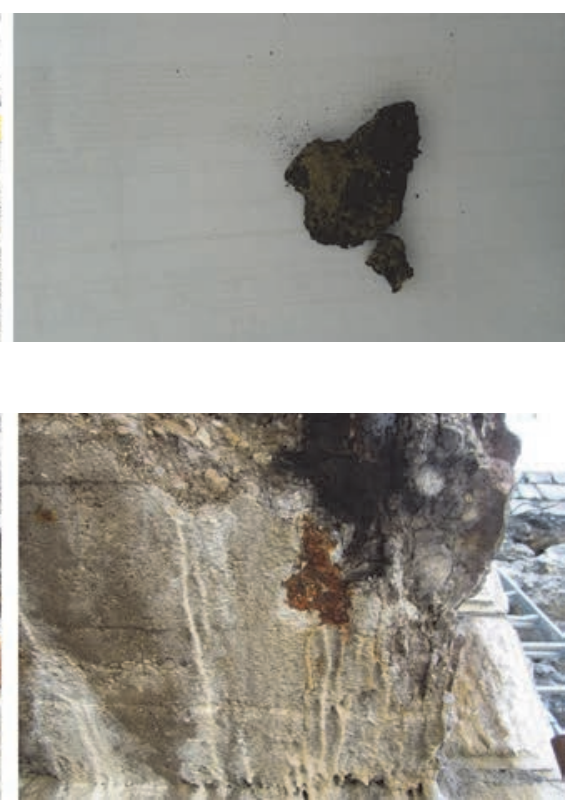

Figure 27 shows all samples taken from the structure.

The analysis of P4 samples has revealed that a different type of concrete was used (Figure 28), and that it is a well structured factory-mixed concrete with dolomite aggregate, most probably originating from the post-war decades of the past century, or from this century. These data

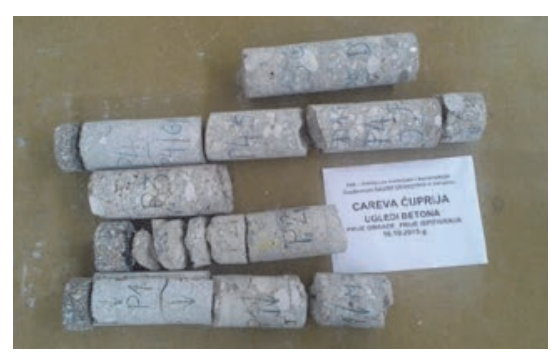

Figure 27. Sample before treatment and testing 
cannot be taken into account when calculating the current class of concrete from the bridge arch because it represents a "new" concrete that was obviously used in bridge repair some ten to fifteen years ago. This concrete sample is completely different from the other samples regarding its structure, where in all other samples river aggregate and another type of cement has been used.

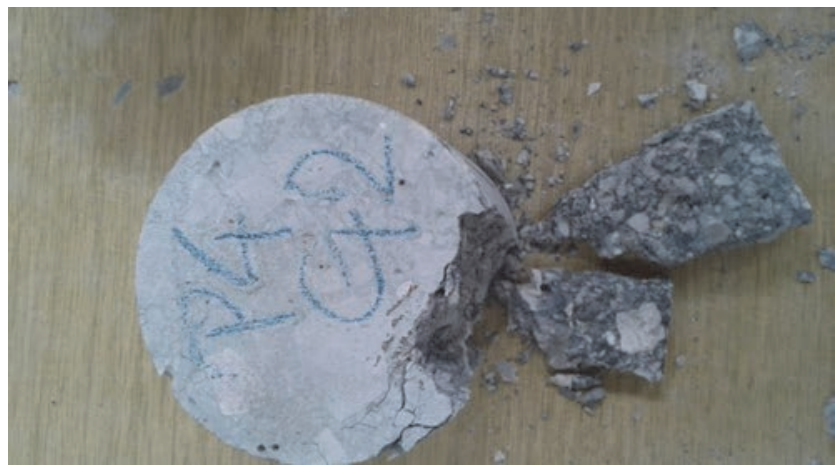

Figure 28. Sample from sidewalk (P4)
All other samples are of different structural composition involving the use of river aggregate (Figure 29) and cement that has, unlike cements produced since the mid twentieth century, a conspicuous change in cement stone colour (darker and lighter shades of brown).

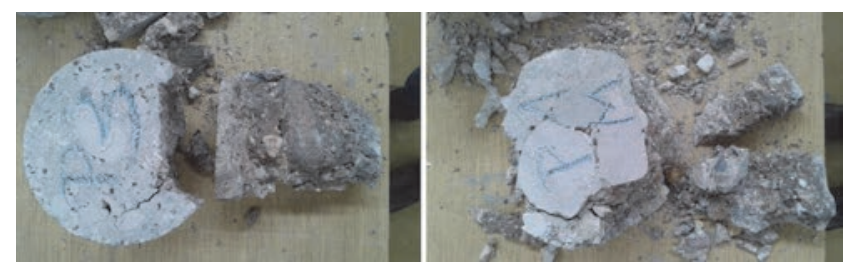

Figure 29. Samples from other parts of the structure

The current concrete class was determined according to criterion one - established production (for determining the quality of placed concrete) [9].

Individual test results for cylindrical cores are shown in Table 2. Samples $\mathrm{P} 4$ were eliminated from the analysis because they do not belong to the same type of concrete, as indicated above. It can clearly be seen in Table 2 that one group exhibits larger value of compressive strength. In fact, soft water (rain water) seepage

Table 2. Sample test results

\begin{tabular}{|c|c|c|c|c|c|c|c|c|c|}
\hline \multirow[b]{2}{*}{ No. } & \multirow[b]{2}{*}{$\begin{array}{l}\text { Structure } \\
\text { element }\end{array}$} & \multirow[b]{2}{*}{ Sample } & \multirow[b]{2}{*}{$\begin{array}{c}\text { Sample } \\
\text { diameter } \\
{[\mathrm{mm}]}\end{array}$} & \multirow[b]{2}{*}{$\begin{array}{c}\text { Sample } \\
\text { height } \\
{[\mathrm{mm}]}\end{array}$} & \multirow[b]{2}{*}{$\begin{array}{c}\text { Sample } \\
\text { weight } \\
\text { [g] }\end{array}$} & \multirow{2}{*}{$\begin{array}{c}\text { Specific } \\
\text { weight of } \\
\text { the sample } \\
{\left[\mathrm{kg} / \mathrm{m}^{3}\right]}\end{array}$} & \multirow{2}{*}{$\begin{array}{l}\text { Load at } \\
\text { failure } \\
\text { of the } \\
\text { sample } \\
\text { [N] }\end{array}$} & \multicolumn{2}{|c|}{ Compressive strength } \\
\hline & & & & & & & & $\begin{array}{c}\text { On cylinder } \\
{\left[\mathrm{N} / \mathrm{mm}^{2}\right]}\end{array}$ & $\begin{array}{c}\text { Reduced on a } \\
\text { cube } \\
a=200 \mathrm{~mm} \\
{\left[\mathrm{~N} / \mathrm{mm}^{2}\right]}\end{array}$ \\
\hline 1 & \multirow{11}{*}{$\begin{array}{c}\text { Arch } \\
\text { structure } \\
\text { of the } \\
\text { Emperor's } \\
\text { Bridge }\end{array}$} & P1 & 101.0 & 101.0 & 1595.29 & 1971 & 165500 & 20.66 & 21.07 \\
\hline 2 & & P1M & 100.0 & 100.8 & 1577.16 & 1992 & 146500 & 18.65 & 19.03 \\
\hline 3 & & P2 & 99.0 & 99.8 & 1499.23 & 1952 & 148500 & 19.29 & 19.68 \\
\hline 4 & & P3 & 99.0 & 99.9 & 1557.12 & 2025 & 168000 & 21.82 & 22.26 \\
\hline 5 & & P4G1 & 99.5 & 98.9 & 1696.68 & 2206 & 451000 & 58.00 & 59.16 \\
\hline 6 & & P4G2 & 99.4 & 99.4 & 1737.86 & 2253 & 469000 & 60.44 & 61.65 \\
\hline 7 & & P4S & 99.5 & 99.7 & 1510.35 & 1948 & 137500 & 17.68 & 18.04 \\
\hline 8 & & P4D1 & 99.5 & 100.0 & 1590.74 & 2046 & 192500 & 24.76 & 25.25 \\
\hline 9 & & P4D2 & 99.5 & 100.2 & 1573.95 & 2020 & 181000 & 23.28 & 23.74 \\
\hline 10 & & P5G & 99.7 & 99.6 & 1665.62 & 2142 & 283000 & 36.25 & 36.97 \\
\hline 11 & & P5D & 99.7 & 99.3 & 1654.43 & 2134 & 302500 & 38.75 & 39.52 \\
\hline
\end{tabular}

1.2. DETERMINATION OF THE CONCRETE CLASS (JUS U M1.048) A. RESULTS FROM THE SAMPLES REDUCED TO THE CURRENT STRENGTH time reduction factor

factor for the concrete strength ratio of structure $\quad 0,85$ CORRECTION FACTOR

1,18

\begin{tabular}{|l|c|c|c|c|}
\hline month & & & & \\
\hline series & 1 & $1-3$ & $4-7-8$ & $9-11$ \\
\hline $\begin{array}{l}\text { Individual data } \\
\text { correction with } \\
\text { reduction factors }\end{array}$ & & 24.79 & 26.19 & 27.93 \\
\cline { 2 - 5 }$(\mathrm{MPa})$ & 22.38 & 21.22 & 43.50 \\
\cline { 2 - 5 } & & 23.15 & 29.71 & 46.50 \\
\hline
\end{tabular}

\section{B. CONTROL OF THE CURRENT GRADE (as per t.3.2.1.)}

\section{MB}

\begin{tabular}{|l|c|c|c|c|}
\hline series (1) & & $1-3$ & $4-7-8$ & $9-11$ \\
\hline mean value & Xsr & 23.44 & 25.71 & 39.31 \\
\hline minimum value & Xmin & 22.38 & 21.22 & 27.93 \\
\hline \multirow{2}{*}{$\begin{array}{l}\text { PBAB criteria } \\
\text { CRITERIA 1. }\end{array}$} & $\mathrm{m}(\mathrm{n})=$ & 23 & 23 & 33 \\
\cline { 2 - 5 } evaluation of MB & X $1=$ & 17 & 17 & 27 \\
\cline { 2 - 5 } & Xmin $>$ X1 & yes & yes & yes \\
\hline Conclusion & Sadašnja MB & 20 & 20 & 30 \\
\hline
\end{tabular}


occurs at the location where these samples were extracted. Due to the soft water seepage, capillaries are being filled, which is manifested by concrete coagulation and increase of density in hardened state. The values of density $\left(2142 \mathrm{~kg} / \mathrm{m}^{3}\right.$ and 2134 $\mathrm{kg} / \mathrm{m}^{3}$ ) and compressive strength on the cube (37.0 MPa and $39.5 \mathrm{MPa}$ ) greatly deviate from all other similar results [8].

Water seepage through concrete is characterised by uneven filtration: the number of filtration channels is the greatest at the beginning of the filtration path, next to concrete surface exposed to pressure. Blockage of filtration occurs due to hydrolytic decomposition of cement stone and swelling of colloidal compounds (mostly calcium hydrosilicate). The process of leaching is significantly slowed down only if the layer depleted and weakened by leaching of lime, which is formed on the surface of concrete, does not fall apart due to mechanical or hydraulic effects (Figure 30). Significant corrosion of concrete can be observed on all samples (Figure 31)
Based on testing of concrete samples taken from the arch of the Careva Cuprija Bridge, the concrete can be classified into quality class MB 20.

According to classification of structural damage according to CEB [10], this structure can be classified into the damage class D. If the level of damage is $C$ or $D$, urgent repair and reconstruction of the structure is needed.

Although the tests were conducted on a small number of samples taken from bridge structure, it can nevertheless be stated that the concrete strength did not reduce as compared to the testing conducted by the Institute in 2007 [7]. However, the bridge structure further deteriorated due to soft water corrosion (corrosion by leaching) as combined with general acid corrosion (soluble gases $\mathrm{CO}_{2}, \mathrm{H}_{2} \mathrm{~S}$ ).

\subsubsection{Determination of alkalinity, content of harmful components (sulphates and chlorides)}

Figure 30. Samples P5 D and P5 G

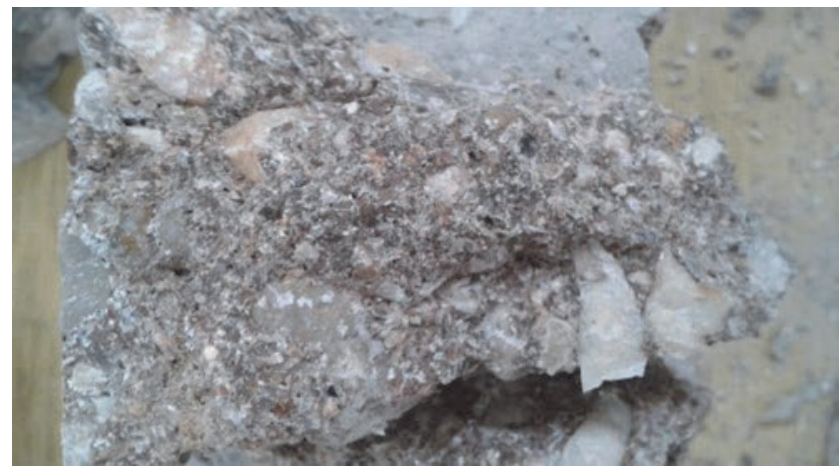

Figure 31. Seepage through concrete

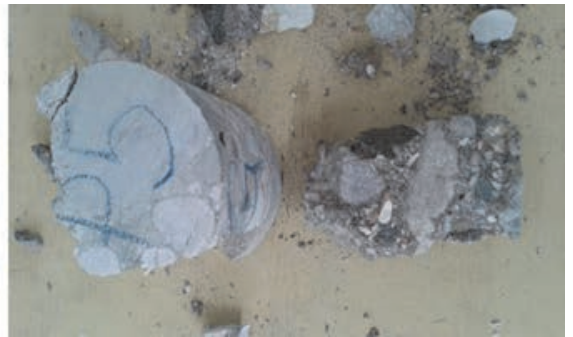

Test samples subjected to compressive strength testing were crushed into powder and analysed to determine their $\mathrm{pH}$, sulphate and chloride content values [8]. Micro-heterogeneous (coarse dispersion) dispersion systems have particles with a diameter greater than $10^{-7} \mathrm{~m}$, while colloidal or ultra-micro-heterogeneous systems have diameters of the dispersed phase ranging from $10^{-7} \mathrm{~m}$ to $10^{-9} \mathrm{~m}$. The dispersion system on which the testing was conducted was obtained by grinding concrete particles to certain sizes (a $90 \mu \mathrm{m}$ sieve was taken for these two dispersion methods).

The sulphate content was determined using a semi quantitative method:

- sulphate ions expressed as $\mathrm{SO}_{4}^{2-}$ according to BS 812: Part 118: 1988 (Sulphate test strips) Quantofix Sulfate; following instructions given by the manufacturer (Macherey - Nagel).

The chloride content was determined using a qualitative method:

Table 3. Damage levels according to CEB [10]

\begin{tabular}{|c|c|c|c|c|c|}
\hline $\begin{array}{l}\begin{array}{r}\text { Damage } \\
\text { level }\end{array} \\
\text { Type } \\
\text { of damage }\end{array}$ & A & B & C & D & E \\
\hline Color changes & rust stains & as in $A$ & as in $A$ & as in $A$ & as in $A$ \\
\hline Cracking & some longitudinal & $\begin{array}{c}\text { several } \\
\text { longitudinal, some } \\
\text { on stirrups }\end{array}$ & extensive & as in $C$ & as in $C$ \\
\hline Spalling & & some & extensive & $\begin{array}{l}\text { in some areas steel is no more } \\
\text { in contact with concrete }\end{array}$ & as in D \\
\hline Loss in steel-section & & $-5 \%$ & $-10 \%$ & $-25 \%$ & $\begin{array}{l}\text { some stirrups broken } \\
\text { main bars buckled }\end{array}$ \\
\hline Deflections & & & & possible & apparent \\
\hline
\end{tabular}


Table 4. Material characteristics used as input data for modelling

\begin{tabular}{|c|c|c|c|c|c|}
\hline Element Parameters & $\begin{array}{c}\mathbf{E} \\
{\left[\mathrm{N} / \mathrm{mm}^{2}\right]}\end{array}$ & Poisson ratio $-v$ & $\begin{array}{c}\text { Density - } \rho \\
{\left[\mathrm{kg} / \mathrm{m}^{3}\right]}\end{array}$ & $\begin{array}{l}\text { Tensile strength } \\
{\left[\mathrm{N} / \mathrm{mm}^{2}\right]}\end{array}$ & $\begin{array}{l}\text { Yielding } \\
{\left[\mathrm{N} / \mathrm{mm}^{2}\right]}\end{array}$ \\
\hline Façade walls & 28500 & 0.20 & 2400 & 1.9 & \\
\hline Arch & 28500 & 0.20 & 2500 & 1.9 & \\
\hline Fill and bulk material & & & 1800 & & \\
\hline Existing steel & 210000 & 0.30 & 7850 & 470 & 285 \\
\hline Steel for strengthening & 210000 & 0.30 & 7850 & 575 & 500 \\
\hline
\end{tabular}

- Chloride ions Cl according to BS 812: Part 117: 1988 (Test Kit for Chloride determination chloride (e) CL 500, following instructions given by the manufacturer (Macherey - Nagel). The $\mathrm{pH}$ value was determined by digital measurement.

Low $\mathrm{pH}$ values were determined, which shows that a good protection of reinforcement cannot be ensured on this basis. For adequate protection of reinforcement against corrosion, the $\mathrm{pH}$ value should amount to at least 11.8 as the corrosion risk amounts to $90 \%$ for $\mathrm{pH}$ values of less than 10 .

It should be emphasized that an extremely high open porosity with considerable absorption of water originating from fill material located above the concrete. In this material a large amount of moisture is deposited, and this moisture drains through the porous structure of concrete. The acidic nature of fill material particles dissolved in water greatly influences a decrease in alkalinity on the top surface of concrete.

The chloride content in concrete varies between $25 \mathrm{mg} / \mathrm{l}$ and $75 \mathrm{mg} / \mathrm{l}$, or reaches up to $0.0075 \%$. The chlorine ions content relative to the quantity of cement in tested samples is within allowed limits, and amounts to $0.05 \%$.

\section{Numerical analysis}

\subsection{Existing structure}

After the experimental tests were conducted on the site and in laboratory, numerical analysis of the existing bridge was made, and structural rehabilitation design of the bridge was prepared and approved by the client [11]. In this regard, it is important to determine structural behaviour of the bridge under static action, and dynamic characteristics of the structure, in order to determine structural behaviour of the bridge during seismic action. The finite element method and the Tower software were used for the analysis of this structure [12]. Shell elements with six degrees of freedom were used in modelling, and the following assumptions were adopted:

- the effects from the walls are not transferred to the arch structure
- the connection of the arch and the abutments does not involve transfer of bending moments, which is quite understandable due to detail of the arch support on the abutment

- number of nodes: 37506; number of shell elements: 35667; and number of boundary elements: 2100 .

Material characteristics obtained by experimental tests, as shown in Table 4, were used to determine the capacity of the structure, and to select appropriate remediation measures.

As the bridge is located in urban setting, it was classified as a Category II structure, according to [13]. For such bridges, the main lane is loaded with a vehicle type-V600 in the most unfavourable location. As the bridge under study was built in 1897, when loads imposed on similar structures were much lower, additional calculations were made for category III and the appropriate load.
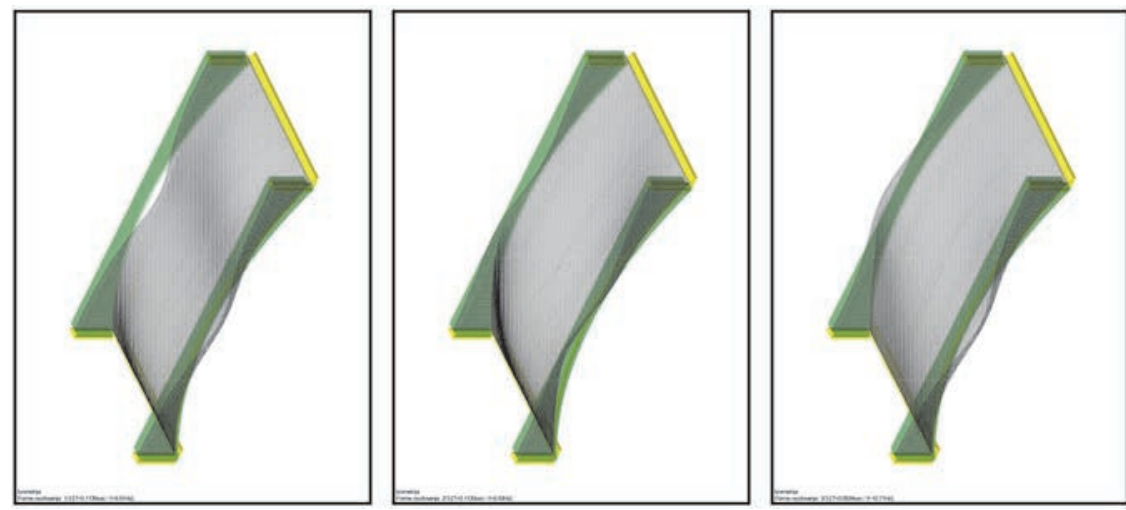

Figure 32. Fundamental modes and frequencies
Table 5. Periods and frequencies

\begin{tabular}{|c|c|c|}
\hline Mode & Period [s] & Frequency [Hz] \\
\hline 1 & 0.1135 & 8.81 \\
\hline 2 & 0.1120 & 8.93 \\
\hline 3 & 0.0934 & 10.71 \\
\hline
\end{tabular}

\subsubsection{Modal analysis}

The modal analysis was performed in the first phase of numerical analysis so as to determine the modes and (fundamental) periods of free vibration. The fundamental periods, frequencies, 
Table 6. Stress state

\begin{tabular}{|c|c|c|c|c|c|c|}
\hline Load combination & $\sigma_{1 \mathrm{~g}}[\mathrm{MPa}]$ & $\sigma_{2 g}[\mathrm{MPa}]$ & $\sigma_{1 d}[\mathrm{MPa}]$ & $\sigma_{2 d}[\mathrm{MPa}]$ & $\sigma_{\text {ug }}[\mathrm{MPa}]$ & $\sigma_{\text {ud }}[\mathrm{MPa}]$ \\
\hline$|+| I+I I I$ & $\begin{array}{c}0.44(V) \text { do } \\
-1.61(T)\end{array}$ & $\begin{array}{c}-0.07(T) \text { do } \\
-4.66(T)\end{array}$ & $\begin{array}{c}0.71(\mathrm{~V}) \text { do } \\
-1.51(\mathrm{~T})\end{array}$ & $\begin{array}{c}0.35(V) \text { do } \\
-3.63(T)\end{array}$ & $\begin{array}{c}0.09(\mathrm{~V}) \text { do } \\
4.67(\mathrm{~V})\end{array}$ & $\begin{array}{c}0.11(\mathrm{~V}) \text { do } \\
3.63(\mathrm{~V})\end{array}$ \\
\hline I+II+III+IV - V600 & $\begin{array}{l}0.73(\mathrm{~V}) \text { do } \\
-2.46(\mathrm{~T})\end{array}$ & $\begin{array}{l}0.20(\mathrm{~V}) \text { do } \\
-8.65(\mathrm{~T})\end{array}$ & $\begin{array}{c}3.29(\mathrm{~V}) \text { do } \\
-2.15(\mathrm{~T})\end{array}$ & $\begin{array}{c}2.37(\mathrm{~V}) \text { do } \\
-5.09(\mathrm{~T})\end{array}$ & $\begin{array}{c}0.03(\mathrm{~V}) \text { do } \\
7.80(\mathrm{~V})\end{array}$ & $\begin{array}{c}0.08(\mathrm{~V}) \text { do } \\
5.08(\mathrm{~V})\end{array}$ \\
\hline$I+I I+I I I+I V-V 300+V 300$ & $\begin{array}{l}0.58(\mathrm{~V}) \text { do } \\
-1.92(\mathrm{~T})\end{array}$ & $\begin{array}{c}0.20(\mathrm{~V}) \text { do } \\
-7.70(\mathrm{~T})\end{array}$ & $\begin{array}{c}2.71(\mathrm{~V}) \text { do } \\
-1.90(\mathrm{~T})\end{array}$ & $\begin{array}{c}1.55(\mathrm{~V}) \text { do } \\
-4.76(\mathrm{~T})\end{array}$ & $\begin{array}{c}0.05(\mathrm{~V}) \text { do } \\
7.02(\mathrm{~V})\end{array}$ & $\begin{array}{c}0.13(\mathrm{~V}) \text { do } \\
4.68(\mathrm{~V})\end{array}$ \\
\hline \multicolumn{7}{|c|}{$\begin{array}{l}\text { Where: } \\
\sigma_{1 \mathrm{~g}} \text { - stress for the direction of the main axis } 1 \text {. on the top side of the plate, } \sigma_{2 \mathrm{~g}} \text { - stress for the direction of the main axis } 2 \text {. on the top side of the plate } \\
\sigma_{1 \mathrm{~d}} \text { - stress for the direction of the main axis } 1 \text {. on the bottom side of the plate, } \sigma_{2 \mathrm{~d}} \text { - stress for the direction of the main axis } 2 \text {. on the bottom side of the plate } \\
\sigma_{\mathrm{ug}} \text { - equivalent stress. on the top side of the plate, } \sigma_{\mathrm{ud}} \text { - equivalent stress. on the bottom side of the plate }\end{array}$} \\
\hline
\end{tabular}

Table 7. Ratio of actual to necessary reinforcement for safety factors required according to regulations for ULS -PBAB87; live load V300+V300

\begin{tabular}{|c|c|c|c|c|c|c|}
\hline Section & $\begin{array}{l}\text { Location of } \\
\text { the section }\end{array}$ & $\begin{array}{c}\text { Amount of built in } \\
\text { reinforcement St 50-2 } \\
A_{\mathrm{st}}\left[\mathrm{cm}^{2} / \mathrm{m}\right]\end{array}$ & $\begin{array}{c}\text { Amount of necessary } \\
\text { reinforcement St 50-2 } \\
A_{\text {pot }}\left[\mathrm{cm}^{2} / \mathrm{m}\right]\end{array}$ & $A_{s t} / A_{p o t}$ & $\begin{array}{c}\text { Amount of necessary } \\
\text { reinforcement } \\
\text { MA 500/560 } A_{\text {pot }}\left[\mathrm{cm}^{2} / \mathrm{m}\right]\end{array}$ & Safety factor \\
\hline$A_{g}$ & $\begin{array}{l}X=25.05 m \\
Y=11.20 m \\
Z=0.12 m\end{array}$ & $\begin{array}{c}\text { Could not be determined } \\
\text { on the spot }\end{array}$ & 5.71 & - & 3.13 & - \\
\hline$A_{d}$ & $\begin{array}{l}X=5.81 \mathrm{~m} \\
Y=4.00 \mathrm{~m} \\
Z=1.86 \mathrm{~m}\end{array}$ & 19.56 & 8.75 & 1.12 & 5.41 & 1.8 \\
\hline
\end{tabular}

and fundamental modes, are shown in Figure 32 and in Table 5. It is evident that this is a very rigid structure.

\subsubsection{Static analysis of the existing structure}

The static analysis was performed in the second phase of the numerical analysis so as to determine behaviour of the structure under self weight and live load for two groups of bridges. Principal tensile and compressive stresses are shown in Table 6.

The equivalent value of stresses was calculated from Miss Eq. (1) based on hypothesis of the maximum deviatoric strain energy.

$\sigma_{\mathrm{u}}=\sqrt{\sigma_{1}^{2}-\sigma_{1} \sigma_{2}+\sigma_{2}^{2}}$

Figure 33 shows the stress state for the load combination + II+III+IV - V300+V300 which was adopted as the structure can not be strengthened using greater load while respecting at the same time the requirement to make as little interventions on the structure as possible.

The ratio of actual to necessary reinforcement for the existing situation as per regulations for required safety factors and the traffic load for V300+V300 is provided in Table 7.

It was established according to calculations that the intrados of the bridge structure will be strengthened with reinforcement meshes (MA 500/560) Q524 and with sprayed concrete class

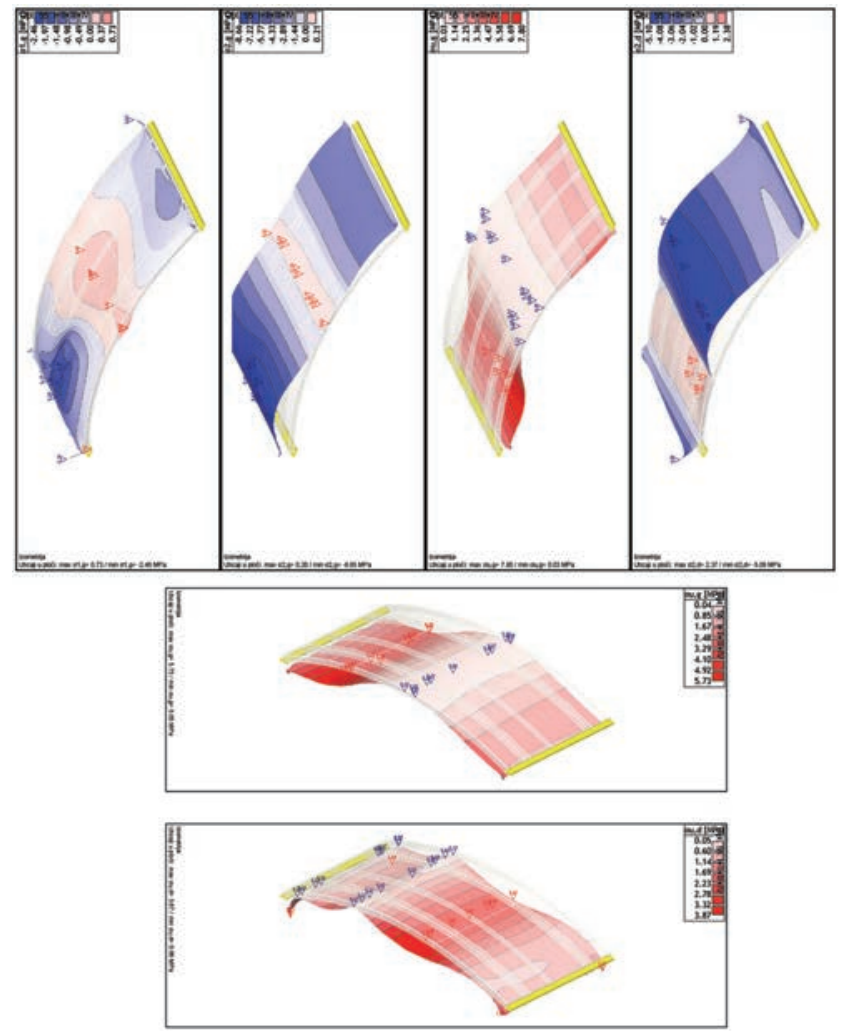

Figure 33. Stresses for load combination with load vehicles V300 + V300 - existing structure: I - dead weight of the structure, II - weight of the fill and bulk material, III - load from top layers and railing weight, IV - type of live load 
Table 8. Stress state

\begin{tabular}{|c|c|c|c|c|c|c|}
\hline Load combination & $\begin{array}{c}\sigma_{1 \mathrm{~g}} \\
{[\mathrm{MPa}]}\end{array}$ & $\begin{array}{c}\sigma_{2 \mathrm{~g}} \\
{[\mathrm{MPa}]}\end{array}$ & $\begin{array}{c}\sigma_{1 \mathrm{~d}} \\
{[\mathrm{MPa}]}\end{array}$ & $\begin{array}{c}\sigma_{2 \mathrm{~d}} \\
{[\mathrm{MPa}]}\end{array}$ & $\begin{array}{c}\sigma_{\mathrm{ug}} \\
{[\mathrm{MPa}]}\end{array}$ & $\begin{array}{c}\sigma_{\mathrm{ud}} \\
{[\mathrm{MPa}]}\end{array}$ \\
\hline$|+| I+|I|$ & $\begin{array}{c}0.56(\mathrm{~V}) \text { do } \\
-2.37(\mathrm{~T})\end{array}$ & $\begin{array}{c}-0.31(T) \text { do } \\
-3.78(T)\end{array}$ & $\begin{array}{c}0.28(\mathrm{~V}) \mathrm{do} \\
-3.04(\mathrm{~T})\end{array}$ & $\begin{array}{c}0.22 \text { (V) do } \\
-3.54(\mathrm{~T})\end{array}$ & $\begin{array}{c}0.35(\mathrm{~V}) \text { do } \\
3.69(\mathrm{~V})\end{array}$ & $\begin{array}{c}0.04(\mathrm{~V}) \text { do } \\
3.20(\mathrm{~V})\end{array}$ \\
\hline$I+I I+I I I+I V-V 300+V 300$ & $\begin{array}{c}0.64(\mathrm{~V}) \text { do } \\
-3.04(\mathrm{~T})\end{array}$ & $\begin{array}{c}0.03(\mathrm{~V}) \text { do } \\
-6.27(\mathrm{~T})\end{array}$ & $\begin{array}{l}1.96(\mathrm{~V}) \text { do } \\
-3.73(\mathrm{~T})\end{array}$ & $\begin{array}{c}1.24(\mathrm{~V}) \text { do } \\
-4.23(\mathrm{~T})\end{array}$ & $\begin{array}{c}0.05(\mathrm{~V}) \text { do } \\
5.73(\mathrm{~V})\end{array}$ & $\begin{array}{c}0.06(\mathrm{~V}) \text { do } \\
3.87(\mathrm{~V})\end{array}$ \\
\hline
\end{tabular}

Table 9. Required amount of reinforcement for the existing state (PBAB87) with mesh reinforcement (MA 500/560). Traffic load V300+V300

\begin{tabular}{|c|c|c|c|c|}
\hline Section & $\begin{array}{l}\text { Location of } \\
\text { the section }\end{array}$ & $\begin{array}{l}\text { Amount of built in reinforcement } \\
\qquad \check{C} 0545 A_{s t}\left[\mathrm{~cm}^{2} / \mathrm{m}\right]\end{array}$ & $\begin{array}{l}\text { Amount of necessary reinforcement } \\
\text { MA 500/560 } A_{\text {pot }}\left[\mathrm{cm}^{2} / \mathrm{m}\right]\end{array}$ & $\begin{array}{l}\text { Adopted reinforcement } A_{\text {usv }} \\
\qquad\left[\mathrm{cm}^{2} / \mathrm{m}\right]\end{array}$ \\
\hline$A_{g}$ & $\begin{array}{l}X=0.18 \mathrm{~m} \\
Y=-0.47 \mathrm{~m} \\
Z=0.08 \mathrm{~m}\end{array}$ & nije se moglo utvrditi na licu mjesta & 4.72 & $\begin{array}{l}\text { Q524 } \\
5.24\end{array}$ \\
\hline$A_{d}$ & $\begin{array}{l}X=5.81 \mathrm{~m} \\
Y=2.12 \mathrm{~m} \\
Z=1.86 \mathrm{~m}\end{array}$ & 19.56 & 4.61 & $\begin{array}{l}\text { Q524 } \\
5.24\end{array}$ \\
\hline
\end{tabular}

MB $2010 \mathrm{~cm}$ in thickness. The extrados will be reinforced with meshes (MA 500/560) Q524 and with sprayed concrete class MB 20 approximately $5 \mathrm{~cm}$ in thickness. Shotcrete is traditionally used to increase the arch thickness in order to increase the carrying capacity, and to stabilize and protect structures exposed to atmospheric conditions. A large number of Victorian masonry bridges and arch structures in England were strengthened in this way [14].
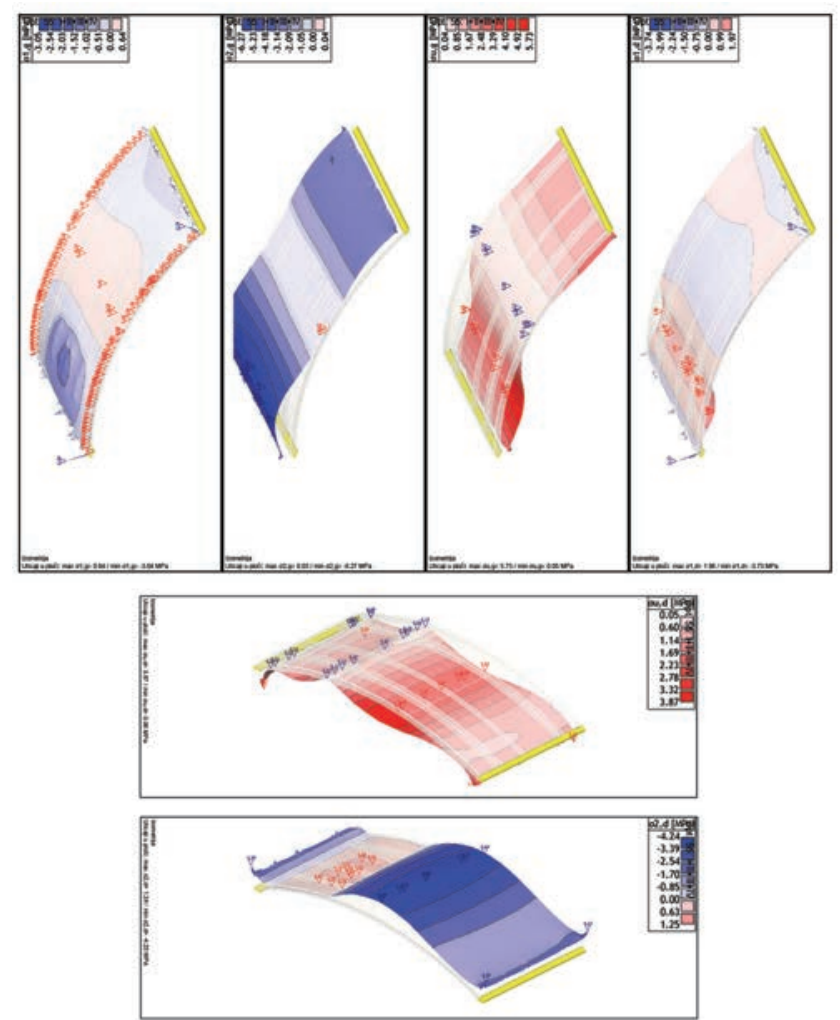

Figure 34. Stresses for load combination with load vehicles V300 + V300 - rehabilitated structure

\subsection{Static analysis of strengthened structure}

Finally, an analysis of the rehabilitated structures was done in accordance with the investor's approval. The stress state of the arch is shown in Table 8 and Figure 34. Table 9 shows the amount of reinforcement needed to take over the tensile stresses.

Reinforcement of the intrados and extrados is shown in Figure 35 together with the anchorage detail that will be used for connection of the top and bottom reinforcement.

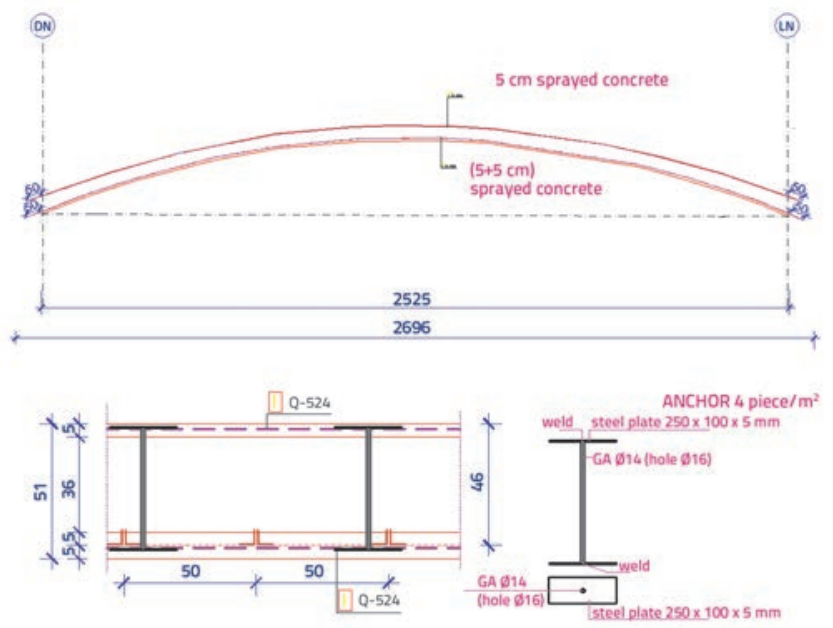

Figure 35. Reinforcement of the arch and anchor detail

\section{Conclusion}

Protection of cultural and historical heritage is very important for the preservation of cultural identity. The goal of protection is not only to preserve the quality but also to extend the life of the structure. This goal can sometimes be achieved with adequate maintenance although certain rehabilitation measures have to 
be undertaken in case of improper use. In doing so, care must be taken to respect the rules of the Venetian Charter and to provide for safe use of these structures. The aim of this research was to determine the condition of the structure, in terms of degradation of materials and carrying capacity of the structure, and to define measures needed for its structural rehabilitation.

Based on investigations conducted on the Careva Cuprija Bridge structure and the corresponding test results, it was found that there is a need for urgent repair and structural rehabilitation of the arch. In this sense, an appropriate loadbearing structure rehabilitation - involving the use of reinforcement mesh on the side of the intrados and extrados - has been proposed, with the goal of making minimum intervention on the bridge. In addition, the entire structure above the intrados has to be replaced which will require participation of experts from the field of cultural and historical heritage, so that the bridge can be restored to its original state from 1897, as shown in Figure 4.

\section{REFERENCES}

[1] Venice-Charter ICOMOS [Online] http://www.international. icomos.org/charters/venice_e, International Charter for the Conservation and Restoration of Monuments and Sites, 1964.

[2] Ademović, N.: Ponašanje zidanih konstrukcija u BiH pri djelovanju potresa s gledišta suvremenih teoretskih i eksperimentalnih saznanja, disertacija, Građevinski fakultet Univerziteta u Sarajevu, 2012 (in Bosnian).

[3] Ademović, N.: Structural and seismic behavior of typical masonry buildings from Bosnia and Herzegovina, MSc thesis. University of Minho, 2011.

[4] http://radiosarajevo.ba/photo/galerija/12787

[5] Ademović, N., privatne fotografije, 2015

[6] Careva Ćuprija historijski spomenik, Odluka Komisije/Povjerenstva za očuvanje nacionalnih spomenika, Službeni glasnik $\mathrm{BiH}$, broj 36/09.

[7] Elaborat o stanju konstrukcije mosta Careva Cuprija, Institut za materijale i konstrukcije od 30.01.2007, broj 244-4/06

[8] Elaborat o izvršenim istražnim radovima sa prijedlogom sanacionih mjera mosta Careva Ćuprija u Sarajevu, IMK, Sarajevo, broj, 04-1-997-257-6/15, oktobar 2015.

[9] Pravilnik o tehničkim normativima za beton i armirani beton i priznata tehnička pravila koja su vezana uz primjenu toga pravilnika, Službeni list 11/87.

[10] Andrade, C., Alonso, C., Gonzales, J.A.: Aproach to the calculation of residual life in corroding concrete reinforcements based on corrosion intesity values, u: $9^{\text {th }}$ European Congress of Corrosion, Ultrech, Neutherlands, Oct. 1989

[11] Projekat konstruktivne sanacije mosta Careva Ćuprija u Sarajevu, Institut za materijale i konstrukcije od 16.11.2015, broj 04-1997-257-7/15

[12] Tower 7, uputstvo za rad sa programom, Radimpex, 2015

[13] Pravilnik o tehničkim normativima za određivanje veličina opterećenja mostova iz 1991. godine, Službeni list SFRJ br.1/91

[14] Page, J.: Repair and strengthening of arch bridges, IABSE reports = Rapports AIPC = IVBH Berichte, pp.565-572 